\title{
DATA DEFICIENT STERNBERGIA COLCHICIFLORA WALDST. \& KIT. (AMARYLLIDACEAE) IN CROATIAN FLORA - REMOVING THE VEIL OF MIST
}

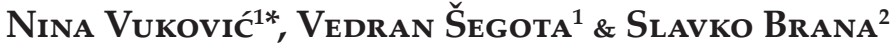

${ }^{1}$ Division of Botany, Department of Biology, Faculty of Science, University of Zagreb, Marulićev trg 20/II, HR-10000 Zagreb, Croatia (nina.vukovic@biol.pmf.hr, vedran.segota@biol.pmf.hr)

${ }^{2}$ Istrian Botanical Society, Trgovačka 45, HR-52215 Vodnjan, Croatia (istra.botanica@gmail.com)

Vuković, N., Šegota, V. \& Brana, S.: Data deficient Sternbergia colchiciflora Waldst. \& Kit. (Amaryllidaceae) in Croatian flora - removing the veil of mist. Nat. Croat., Vol. 26, No. 2., 261-269, Zagreb, 2017.

Sternbergia colchiciflora is a rare species in Croatia, estimated as data deficient (DD), and therefore every new finding represents a valuable contribution to the knowledge of its distribution, with implications for its conservation status in the future. In this paper we describe newly found localities, and provide observations on its current distribution and IUCN status, based on all known sites and population trends. So far, this taxon has been recorded only at a few localities along the Eastern Adriatic coast. Here, we report Mt Velebit and Krka National Park as new localities for S. colchiciflora, and confirm its occurrence on Mt Biokovo and on the island of Brač. The species typically occupies dry calcareous grasslands within eu- and sub-Mediterranean vegetation in different stages of vegetation succession.

Keywords: dry Mediterranean grasslands, IUCN, rare species, Sternbergia colchiciflora var. dalmatica, succession

Vuković, N., Šegota, V. \& Brana, S.: Nedovoljno poznata Sternbergia colchiciflora Waldst. \& Kit. (Amaryllidaceae) u hrvatskoj flori - uklanjanje vela tajni. Nat. Croat., Vol. 26, No. 2., 261-269, Zagreb, 2017.

Sternbergia colchiciflora je u Hrvatskoj rijetka vrsta, procijenjena kao nedovoljno poznata (DD), stoga svaki novi nalaz predstavlja značajan doprinos poznavanju njezine rasprostranjenosti te može imati implikacije na očuvanje ove vrste u budućnosti. U ovom radu opisujemo nove lokalitete, te prilažemo opažanja o trenutnoj rasprostranjenosti i IUCN statusu, temeljem svih dosadašnjih poznatih nalaza i opaženog populacijskog trenda. Ova svojta je do sada bila zabilježena na svega nekoliko lokaliteta duž istočno jadranske obale. U ovom radu prilažemo dva nova lokaliteta (Velebit i NP "Krka"), te potvrđujemo njezino pojavljivanje na Biokovu i Braču. Ova vrsta tipično nastanjuje suhe, vapnenačke kamenjarske travnjake eu- i submediteranske vegetacije, u različitim stadijima vegetacijske sukcesije.

Ključne riječi: suhi sredozemni travnjaci, IUCN, rijetka vrsta, Sternbergia colchiciflora var. dalmatica, sukcesija

\section{INTRODUCTION}

According to Flora Europaea (Wевв, 2010), the genus Sternbergia is represented in Europe by two species: Sternbergia lutea (L.) Ker. Gawl. Ex Spring and S. colchiciflora Waldst. \& Kit., both recorded in the Croatian flora as well (NiKolić, 2017). Due to the broad distribution ranges, certain populations of both species are sometimes recognized as distinct varieties, subspecies, or even separate species (for example

* corresponding author 
S. sicula Tineo ex Guss., S. greuteriana Kamari \& Artelari; see PAsche \& Kerndorff, 2002). Sternbergia colchiciflora is found in Southern Europe, extending northwards to Hungary. It is a winter-growing, hysteranthous geophyte, with an extremely short flowering time, occurring during late summer/ autumn before the appearance of leaves (Fig. 1b,c). Fruiting period is in the spring, while during summer the species is dormant and survives in the form of a bulb.

In Croatia, S. colchiciflora is considered to be very rare. The first findings are from the early $19^{\text {th }}$ century, when REICHENBACH (1830) described S. colchiciflora var. dalmatica using plant material from the vicinity of Zadar. In his work, REICHENBACH (1830) distinguished the Dalmatian variety from the typical species as follows: "Humilior, flore minore laete flavo partitionibus angustioribus tubum subaequantibus, stylo stamina excedente. In planta hungarica flos pallide lutens, partitiones tubum ad minimum sesquilongae vel duplum, et stylus stamina aequat" [Smaller, flowers smaller bright yellow, with narrow segments almost as long as the tube, style longer than the stamens. In Hungarian plants, flowers pale yellow, segments at least equal, up to twice as long as the tube, style as long as the stamens].

Approximately at the same time Petter (1832) and Alschinger (1832) also found S. colchiciflora near Zadar, and finally VISIANI (1842) confirmed this locality, noting that the plants from Dalmatia differ from the typical form according to ReIchenBACH (1830). In his work, Visiani also found S. colchiciflora var. dalmatica in Pokrovnik, in the vicinity of Drniš (VIsIANI, 1842). Findings from Zadar and Drniš were
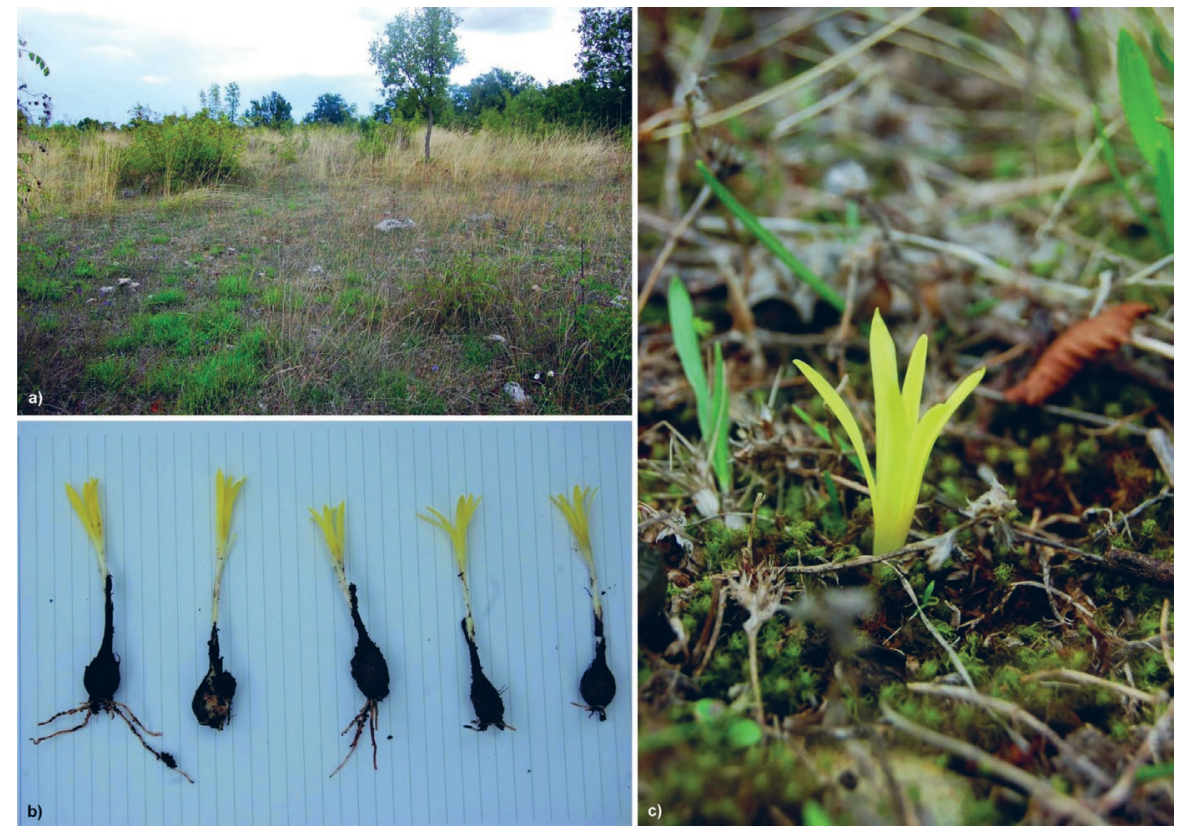

Fig. 1. Sternbergia colchiciflora var. dalmatica in Miljevački Bogatići. a) habitat with dry remnants of Chrysopohon gryllus occurring more abundantly in the background, b) habitus, c) flower.

cited, but never confirmed later in the field (PAvletić, 1964; ŠIlić, 1967; ŠIlić \& Šolić, 1999), although the species was sought in more recent times, at the locality near Zadar (S. Bogdanović, unpublished data). Another locality from the $19^{\text {th }}$ century was detected in the surroundings of Rijeka (Schlosser and Vukotinović ZA-17143), referring to S. colchiciflora, also cited later, but never confirmed in the field (PAvletić, 1964; ŠIlić, 1967; Šilić \& Šolić, 1999).

In the $20^{\text {th }}$ century, a few new localities have been reported in literature, broadening the known distribution of this species towards the south of Croatia; S. colchiciflora var. dalmatica was recorded on the island of Brač (Pavletić, 1964) and Mt Biokovo (Šilić \& Šolić, 1999), while Milović (1998) recorded it (without any varietal rank) for Dubrava near Šibenik. 
In the most recent times there have been only two records of S. colchiciflora in Croatia, stored in the FCD (NiкоLIĆ, 2017) as unpublished observations. These refer to the confirmation of the Brač locality by Ruščı́c $(2008,2009)$, and a photograph made by Z. Cunjak in Garovača, near the Krupa River (BorovečKI-VosKA, 2016).

The aim of our paper is to present our own observations of the populations on the island of Brač, Mt Biokovo, and the southern part of Mt Velebit, and to describe in detail the newly found population in Krka National Park. In addition, we aim to review all known sources of data for this species in Croatia, and present the overview of its occurrence through history. Finally, we present our assessment of its IUCN status, based on the currently known distribution and population trends.

\section{MATERIALS AND METHODS}

During fieldtrips to southern Velebit and Biokovo mountains, as well as the island of Brač, performed in the period 1980-2004, we sporadically collected records on the occurrence of $S$. colchiciflora var. dalmatica in these areas.

Most recently, on September $18^{\text {th }} 2016$ we visited Krka National Park in Northern Dalmatia, with the aim of checking on the flora of dry Mediterranean grasslands of Scorzoneretalia villosae Kovačević 1959, normally distributed in this area. Special attention was paid to the area of Miljevački Bogatići, situated on the plateau above Roški slap (Fig. 2). GPS coordinates were recorded at two sites, and lists of surrounding flora were prepared. Specimens of S. colchiciflora were collected, identified according to Reichenbach (1830) and deposited in the Herbarium Croaticum (Šegota and Vuković ZA-41739).

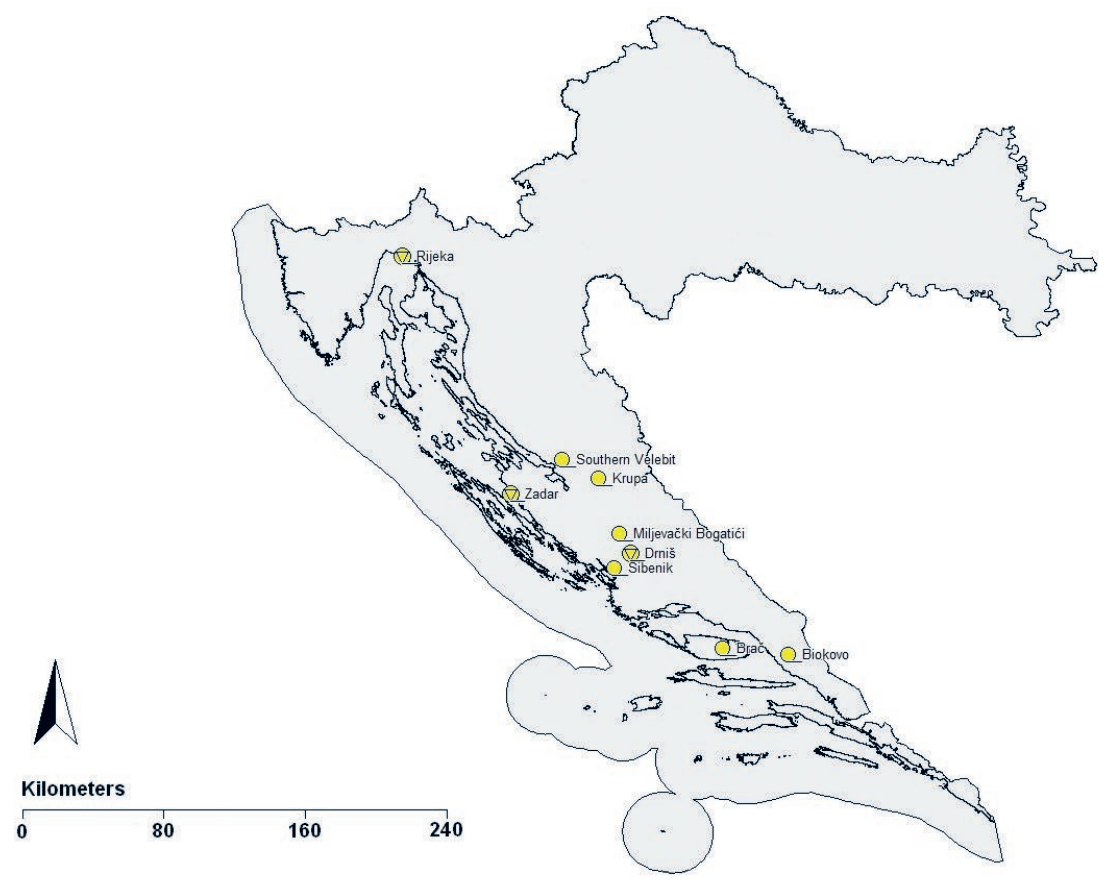

Fig. 2. Geographical position of all known localities of S. colchiciflora var. dalmatica in Croatia. Historical records from the $19^{\text {th }}$ century are shown with a triangle inside a circle. 


\section{RESULTS AND DISCUSSION}

In Tab. 1 we present our field records of S. colchiciflora var. dalmatica in Croatia. Populations on Mt Biokovo, South Velebit and the island of Brač were, with no exception, recorded on south-facing slopes. Plants were growing within dry, Mediterranean grasslands, on open sites with quite deep soil accumulated between the rocks. Although S. colchiciflora was previously recorded on South Velebit by Forenbacher (1990), in the area of Jurline, this finding should be further checked. Namely, the record is accompanied by a photograph that does not represent $S$. colchiciflora, but resembles its relative $S$. lutea, possibly because of a typing error. Nevertheless, we have confirmed the existence of S. colchiciflora var. dalmatica on South Velebit between Veliko Libinje and Šarića pećina, although only a few plants were recorded in 1988, and are possibly even overgrown by surrounding vegetation by now. This finding, however, indicates that even in more recent times, this taxon might have been present in the area of South Velebit.

Tab. 1. Localities of S. colchiciflora var. dalmatica registered during our fieldwork with GPS coordinates given in Gauss-Krueger.

\begin{tabular}{|l|l|c|c|c|}
\hline Locality & & X & Y & Date \\
\hline South Velebit & $\begin{array}{l}\text { Between Veliko Libinje } \\
\text { and Šarića pećina }\end{array}$ & 5547351 & 4905364 & Sep 1988 \\
\hline Mt Biokovo & $\begin{array}{l}\text { Near Katun, below } \\
\text { Glogovik hill }\end{array}$ & 5671373 & 4793568 & Sep 20 1990 \\
\hline Island of Brač & Veliki Gažul & - & - & Sep $16^{\text {th }} 2000$ \\
\hline Island of Brač & Mali Gažul & - & - & Sep $16^{\text {th }} 2000$ \\
\hline Island of Brač & Kadujno brdo & - & Sep $19^{\text {th }} 2004$ \\
\hline Krka National Park & Miljevački Bogatići 1 & 5579470 & 4863187 & Sep $18^{\text {th }} 2016$ \\
\hline Krka National Park & Miljevački Bogatići 2 & 5580406 & 4861140 & Sep $18^{\text {th }} 2016$ \\
\hline
\end{tabular}

In Krka National Park, S. colchiciflora var. dalmatica was found growing by the macadam road leading towards Oziđana pećina, situated on a flat plateau just above the river canyon near Roški slap (Fig. 2). All individuals were identified as S. colchiciflora var. dalmatica. They were recorded on dry Mediterranean grasslands (ass. Koelerio splendenti-Festucetum illyricae Horvatić 1963; Trinajstić 1992), clearly in danger of being overgrown by shrubs, mostly Juniperus deltoides R.P.Adams (see Roma-Marzio et al., 2017) and Paliurus spina-christi Mill. (Fig. 1a). The area of approximately several hundreds of meters of road length was searched more closely, and S. colchiciflora var. dalmatica was found on many sites, growing continuously in a wider area surrounding the road. On our way back, we searched another locality approximately $2 \mathrm{~km}$ from the first site, and found S. colchiciflora var. dalmatica. Although we detected only two individuals on the second site, we believe that the taxon occurs over a broader area. Tab. 2 presents plant lists recorded at these two localities, showing the presence of typical species of dry, calcareous, Mediterranean grasslands, as well as some shrubs and trees, indicating signs of succession.

At the first locality, where Sternbergia colchiciflora var. dalmatica occurs more abundantly, we noticed that the number of individuals tends to decrease with the distance from the road, i.e. when the grassland vegetation becomes more abundant. Sternbergia colchiciflora var. dalmatica was clearly more numerous on open surfaces near the road, in comparison with fully developed grassland. We noticed that the occurrence of robust tufts of Chysopogon gryllus (L.) Trin. does not allow the development of S. colchiciflora var. dalmatica, for this plant requires patches of open ground, leading to conclusion that vegetation succession represents a direct threat to its populations. 
Tab. 2. Plant taxa recorded in the area of Miljevački Bogatići. Coordinates are given in Gauss-Krueger.

\begin{tabular}{|c|c|c|}
\hline & Site 1 & Site 2 \\
\hline NP Krka & 5579470 & 5580406 \\
\hline Miljevački Bogatići & 4863187 & 4861140 \\
\hline Allium sphaerocephalon L. & + & \\
\hline Argyrolobium zanonii (Turra) P.W.Ball & + & \\
\hline Asparagus acutifolius L. & + & + \\
\hline Avena barbata Pott ex Link & & + \\
\hline Bellis sylvestris Cirillo & + & \\
\hline Bromopsis erecta (Huds.) Fourr. & + & \\
\hline Bupleurum veronense Turra & + & + \\
\hline Carex caryophyllea Latourr. & + & \\
\hline Carlina corymbosa $\mathrm{L}$. & + & + \\
\hline Centaurea spinosociliata Senus & + & + \\
\hline Chrysopogon gryllus (L.) Trin. & + & + \\
\hline Convolvulus cantabrica L. & + & + \\
\hline Dactylis glomerata $\mathrm{L}$. & + & + \\
\hline Dasypyrum villosum (L.) P.Candargy & & + \\
\hline Delphinium peregrinum $\mathrm{L}$. & & + \\
\hline Dichanthium ischaemum (L.) Roberty & + & + \\
\hline Eryngium amethystinum L. & + & + \\
\hline Euphorbia spinosa L. & + & + \\
\hline Festuca rupicola Heuff. & + & + \\
\hline Festuca valesiaca Schleich. ex Gaudin & + & + \\
\hline Fumana procumbens (Dunal) Gren. \& Godr. & + & \\
\hline Galium lucidum All. & + & \\
\hline $\begin{array}{l}\text { Helianthemum nummularium (L.) Mill. subsp. } \\
\text { glabrum (Koch) Wilczek }\end{array}$ & + & + \\
\hline $\begin{array}{l}\text { Hypericum perforatum L. subsp. veronense (Schrank) } \\
\text { H. Lindb. }\end{array}$ & + & \\
\hline Juniperus deltoides R.P.Adams & + & + \\
\hline Koeleria splendens C.Presl & + & + \\
\hline Lactuca viminea (L.) J.Presl \& C.Presl & + & \\
\hline Linum tenuifolium $\mathrm{L}$. & + & \\
\hline Lomelosia brachiata (Sm.) Greuter \& Burdet & & + \\
\hline Marrubium incanum Desr. & & + \\
\hline Medicago prostrata Jacq. & & + \\
\hline Melica ciliata $\mathrm{L}$. & & + \\
\hline Nigella damascena L. & + & \\
\hline
\end{tabular}


Tab. 2. Continued

\begin{tabular}{|c|c|c|}
\hline & Site 1 & Site 2 \\
\hline Paliurus spina-christi Mill. & + & + \\
\hline Petrorhagia saxifraga (L.) Link & + & + \\
\hline Pistacia terebinthus L. & & + \\
\hline Plantago lanceolata L. & + & \\
\hline Potentilla recta $\mathrm{L}$. & + & + \\
\hline $\begin{array}{l}\text { Poterium sanguisorba subsp. muricatum Spach ex } \\
\text { Bonnier \& Layens }\end{array}$ & & + \\
\hline Prospero elisae Speta & + & + \\
\hline Quercus pubescens Willd. & + & \\
\hline Rubus ulmifolius Schott & + & \\
\hline Sedum acre L. & + & \\
\hline Sedum ochroleucum Chaix & + & \\
\hline Sedum sexangulare $\mathrm{L}$. & + & \\
\hline Sesleria autumnalis (Scop.) F.W.Schultz & + & \\
\hline Silene otites (L.) Wibel & + & + \\
\hline Stachys thirkei K.Koch & + & + \\
\hline $\begin{array}{l}\text { Sternbergia colchiciflora Walds. \& Kit. var. dalmatica } \\
\text { Reich. }\end{array}$ & + & + \\
\hline Teucrium chamaedrys L. & + & \\
\hline Teucrium polium $\mathrm{L}$. & + & + \\
\hline Trifolium angustifolium L. & + & \\
\hline Trifolium scabrum L. & + & + \\
\hline Trifolium stellatum L. & + & \\
\hline
\end{tabular}

Literature sources provide different notes on the habitat occupied by S. colchiciflora var. dalmatica. In the first record after the historical ones, PAVLETić (1964) recorded the plants within the grassland of Stipo bromoidis-Salvietum officinalis Horvatic 1963, followed by the remark that S. colchiciflora var. dalmatica could be characteristic for this type of grassland. On the other hand, on Mt Biokovo it was found growing on open areas within thin Pinus halepensis forest, and in stands belonging to Quercetalia pubescentis (ŠILIć \& Šolić 1999), while we have found it within the grassland of Koelerio splendenti-Festucetum illyricae Horvatić 1963. Similarly, grasslands in Garovača have been identified as belonging to the same alliance, Chrysopogono grylli-Koelerion splendentis Horvatić 1973 (BOROVEČKIVoska, unpublished data). Previous findings on Brač refer to dry, rocky grasslands in succession with garrigue and macchia of different Mediterranean vegetation types (Ruščı́, 2008, 2009). Therefore, we can conclude that $S$. colchiciflora var. dalmatica typically occupies dry, thermophilous, calcareous habitats within eu- and sub-Mediterranean vegetation in different stages of vegetation succession. It prefers open, southerly exposed grasslands, characterized by the presence of significant number of steppic elements.

Fig. 2 represents the known records of $S$. colchiciflora in Croatia. After studying all known literature and herbarium sources, we have concluded that all Croatian records refer to S. colchiciflora var. dalmatica, as previously indicated by other authors (PAvletić, 1964; Šilić \& Šilić, 1999). The 
species was never recorded as a typical form, while most records (from Zadar and its surroundings, around Drniš, on the island of Brač, on Mt Biokovo) specifically refer to S. colchiciflora var. dalmatica (Reichenbach, 1830; Visiani, 1842; Pavletić, 1964; Šilić \& Šolić, 1999). Although the record from Šibenik (Milović, 1998) refers to the species without any varietal rank, herbarium examples (Milović ZA-17142) have revealed that it was in fact S. colchiciflora var. dalmatica that was concerned. Out of all published data, only records from Rijeka (Schlosser and Vukotinović ZA-17143), and Garovača near the Krupa River (BorovečKI-VoskA, 2016) could not be identified at varietal level, however we believe that all records from the Eastern-Adriatic coast refer to S. colchiciflora var. dalmatica.

In his work on the flora of the Balkan peninsula, НАYек (1932-1933) describes the range of the typical S. colchiciflora as Serbia, Bulgaria, Thrace, Macedonia and Greece, whilst Dalmatia is given as the range for $S$. colchiciflora var. dalmatica. Other than along the Croatian littoral, this variety is known from neighbouring Bosnia and Herzegovina, occurring, however, at localities where the Mediterranean influence is still pronounced (Silić, 1967). Altogether, S. colchiciflora var. dalmatica seems to occur exclusively in the broader area of the Eastern Adriatic. Some authors believe that S. colchiciflora var. dalmatica may be a synonym of S. colchiciflora var. aetnensis, distributed in Spain, Southern Italy and Greece (PAVletić, 1964; ŚIlić, 1967). Comparative studies were started by Šilić; however to our knowledge, these data were never published (ŠILIć, 1967).

Since the records from the surroundings of Rijeka and Zadar were never confirmed after the $19^{\text {th }}$ century, we presume that the species is lost from these localities. In addition, we have observed a clear trend of habitat loss at the studied localities on Brač, Mt Biokovo and in Krka National Park due to the abandonment of traditional pasturing, a key condition for the maintenance of dry Mediterranean grasslands. During several decades of visits to the field, Hršak (unpublished data) observed that the grasslands of Krka National Park are clearly undergoing vegetation succession, significantly reducing the area of open grassland in favour of shrubs and trees. Our own observations have shown that vegetation succession heavily reduces the quality of habitat, whereas these plants require open patches for optimal growth, and are easily outcompeted by plants that are more robust.

Although the finding from Pokrovnik near Drniš was not subsequently confirmed, we believe that the wider area of Krka River canyon and corresponding grasslands are likely to be occupied with S. colchiciflora var. dalmatica, especially because Pokrovnik is situated between the two localities with more recent records of this species (Dubrava near Šibenik and Miljevački Bogatići).

Considering the new knowledge on the distribution and habitat trends of S. colchiciflora var. dalmatica, we have re-evaluated its data deficient (DD) status according to the most recent IUCN Guidelines (2013). According to our observations, the population is threatened by habitat loss, caused by the abandonment of traditional pasturing. Accordingly, we have observed a continuing decline of the extent of occurrence, area of occupancy, area and quality of habitat, number of locations and subpopulations and number of mature individuals, and estimated this taxon as endangered (EN), under the criteria Blab(i,ii,iii,iv,v)+2ab(i,ii,iii,iv,v). Apart from previously mentioned declines, the estimation is based on the extent of occurrence (EOO) of $3400 \mathrm{~km}^{2}$, and area of occupancy (AOO) of $24 \mathrm{~km}^{2}$, as well as 5 locations with populations confirmed within the last 50 years (South Velebit, Garovača near the river of Krupa, area between Miljevački Bogatići and Šibenik, Mt Biokovo and Brač). Although it was not possible to assess the intensity of threat for every locality, we can say for certain that the intensity is not the same on all localities. For example, we observed that the intensity of vegetation succession and habitat loss is clearly more pronounced on Brač than on Mt Biokovo. Confirming our observations, in Italy the species was estimated as Near Threatened (NT), due to the habitat loss caused by abandonment of traditional land use (Frignani et al., 2010).

It is important to emphasize that $S$. colchiciflora var. dalmatica is an elusive species. It has rather small, yellow flowers blooming in late summer/autumn before the emergence of leaves (Fig. $1 b, c)$, and is easily overlooked among dried remains of the summer vegetation. We returned to Miljevački Bogatići after one week and observed that the plants were still in bloom; however, ŠILIć \& Šolić (1999) noted a very short phenophase of flowering, only few days long. Moreover, a high percentage of cleistogamy was observed in Italian populations, often exceeding 70\% (PERUZZI et al., 2006). Due to the above mentioned features, and the fact that the autumn season is understudied by botanists, it is possible that this taxon has been overlooked in some areas, and new populations could be discovered in the future. Therefore, we believe that its distribution is wider than currently thought and future estimations of its IUCN status might show a different category. 
It is necessary to emphasize the importance of grassland monitoring and maintenance, in the context of preserving grassland species, which require openness of vegetation cover for their optimal growth. In particular, we have observed that $S$. colchiciflora var. dalmatica is outcompeted not only by shrubs and trees, but also by grasses that are more robust; it is therefore especially sensitive to succession.

\section{ACKNOWLEDGMENTS}

The authors would like to thank Sandro Bogdanović for providing most valuable advice on the preparation of the manuscript.

Received April 20, 2017

\section{REFERENCES}

Alschinger, A., 1832: Flora Jadrensis. Typographia Battara, Jaderae. pp 248.

Borovečki-Voska, Lj., 2016: Sternbergia colchiciflora Waldst. et Kit. In: Nikolić, T. (ed.) Flora Croatica Database. Faculty of Science, Zagreb. URL: http://hirc.botanic.hr/fcd.

Frignani, F., Geri, F., Gestri, G. \& Peruzzi, L., 2010: Distribution of the genus Sternbergia Waldst. \& Kit. (Amaryllidaceae) in Tuscany (Central Italy). Atti della Società Toscana di Scienze Naturali, Memorie, serie B, 116 (2009), 67-71.

Forenbacher, S., 1990: Velebit and its flora (In Croatian). Školska knjiga, Zagreb. pp 800.

HayeK, A., 1932-1933: Prodromus Florae Balcanicae. Band 3. Monocotyledoneae. Dahlem, Berlin. pp 472.

IUCN, 2013: Guidelines for Using the IUCN Red List Categories and Criteria. Version 10. Standards and Petitions Subcommittee of the IUCN Species Survival Commission.

MiLović, M., 1998: The flora of Šibenik and its surroundings. Natura Croatica 11, 171-223.

Nikolić, T., (ed.) 2017: Flora Croatica Database. Faculty of Science, Zagreb. URL: http://hirc.botanic.hr/ fcd.

Pasche, E. \& Kerndorff, H., 2002: Die Gattung Sternbergia Waldst. \& Kit. (Asparagales, Amaryllidaceae) im Vergleich, unter besonderer Berücksichtigung der wiederentdeckten Sternbergia schubertü Schenk. Stapfia 80, 395-416.

Pavletić, Zi., 1964: New locality of the species Sternbergia colchiciflora W. K. var. dalmatica Rchb. (In Croatian). Acta Botanica Croatica 23, 148-150.

Peruzzi, L., Gargano, L., Bernardo, L. \& Tison, J.M. 2006: Osservazioni distributive e cariologiche su Sternbergia colchiciflora Waldst. et Kit. (Amaryllidaceae) nel Parco Nazionale del Pollino. Informatore Botanico Italiano 38, 537-539.

Petter, F., 1832: Botanischer Wegweiser in der Gegend von Spalato in Dalmatien. Battara, Zara. pp 144.

Reichenbach, L,. 1830: Flora Germanica Excursoria. Sectio Prima. Apud Carolum Cnobloch, Lipsiae. pp 136.

Roma-Marizio, F., Najar, B., Alessandri, J., Pistelli, L. \& Peruzzi, L., 2017: Taxonomy of prickly juniper (Juniperus oxycedrus group): A phytochemical-morphometric combined approach at the contact zone of two cryptospecies. Phytochemistry 141, 48-60.

Ruščić, M., 2008: Sternbergia colchiciflora Walds. et Kit. In: Nikolić, T. (ed.) Flora Croatica Database. Faculty of Science, Zagreb. URL: http://hirc.botanic.hr/fcd.

Ruščić, M., 2009: Sternbergia colchiciflora Walds. et Kit. In: Nikolı́, T. (ed.) Flora Croatica Database. Faculty of Science, Zagreb. URL: http://hirc.botanic.hr/fcd.

ŠILIĆ, Č., 1967: Sternbergia colchiciflora W. K. var. dalmatica Rchb. in the flora of Yugoslavia (In Croatian). Glasnik Zemaljskog muzeja Bosne i Hercegovine u Sarajevu. Prirodne nauke. Nova serija 5. NP “Oslobođenje", Sarajevo, 115-122.

ŠIlić, Č. \& Šolić, M.E., 1999: Sternbergia colchiciflora Waldst. et Kit. var. dalmatica Reichenb. on the Biokovo massif (Croatia). Natura Croatica 8, 155-160.

Visiani, R., 1842: Flora Dalmatica. Vol. 1. Apud Fridericum Hofmeister, Lipsiae. pp 252.

Webb, D.A., 2010: Sternbergia Waldst. \& Kit. In: Tutin, T.G., Heywood, V.H., Burges, N.A., Moore, D.M., VAlentine, D.H., Walters, S.M. \& Webb, D.A., (eds.) Flora Europaea vol 5. Alismataceae to Orchidaceae. Cambridge University Press, New York. pp 506. 


\title{
SUMMARY
}

\section{Data deficient Sternbergia colchiciflora Waldst. \& Kit. (Amaryllidaceae) in Croatian flora - removing the veil of mist}

\begin{abstract}
N. Vuković, V. Šegota \& S. Brana
Sternbergia colchiciflora, with three known varieties, occurs throughout Southern Europe. The species is rare in Croatia, so far estimated according to IUCN protocol as data deficient (DD). It had been registered only in few localities along the Eastern-Adriatic coast, but some of these findings were never confirmed after the $19^{\text {th }}$ century. In this context, new findings represent a valuable contribution to the knowledge of its distribution, with implications on its conservation status in the future. In this paper, we discuss all known records of this taxon in Croatia, and describe newly found localities. Furthermore, we provide observations on its regional IUCN status, and propose its assignment into the category endangered (EN), based on all known sites and population trends. We report Mt. Velebit and National park "Krka" as new localities for S. colchiciflora, and confirm its occurrence on Mt. Biokovo and on the island of Brač. We believe that all Croatian populations refer to Sternbergia colchiciflora var. dalmatica. This variety typically occupies dry calcareous grasslands within submediterranean vegetation in different stages of vegetation succession. It prefers open ground to fully developed grassland, and it is sensitive to overgrowing. Grassland monitoring and maintenance are of key importance for preserving populations of Sternbergia colchiciflora var. dalmatica.
\end{abstract}

